\title{
SCANNING ELECTRON MICROSCOPY AND X-RAY SPECTROSCOPY APPLIED TO MYCELIAL PHASE OF SPOROTHRIX SCHENCKII *
}

\author{
M. Thibaut ** and M. Ansel ***
}

\begin{abstract}
Scanning electron microscopy applied to the mycelial phase of Sporothrix schenckii shcw.s a matted mycelium with conidia of a regular pattern. X-Ray microanalysis applied in energy dispersive spectroscopy and also in wavelength aispersive spectroscopy reveals the presence of several elements of Mendeleef's classification.
\end{abstract}

\section{INTRODUCTION}

Elemental microanalysis as effected under the scanning electron microscope equipped with X-Ray spectrometers permits the detection in a sample of all the elements of Mendeleef's classification comprised between Berylium and Uranium. We thought it advisable to apply this technique to our research on pathogenic fungi in Man. The present paper reports our results on the mychelial phase of Sporothrix schenckii.

\section{MATERIAL AND METHODS}

Five days' cultures of Sporothrix schenckii $(1 ; 2)$ are completely cleared of their food material (Sabouraud glucose agar). For scanning electron microscupy, the cultures are fixed at $+4^{\circ}$ for 24 hours in
5\% glutaraldehyde in phosphate buffer, pH 7,2 , then in $2 \%$ osmium introxide in the same buffer for 2 hours. After fixaction, they are carried over to aluminium slide - cylinders and stuck on them with silver lacquer so as to secure tine conductivity of the electrons. Then they are frozen in liquid nitrogen at $-180^{\circ} \mathrm{C}$ and examined with Jem $50 \mathrm{~A}$ scanning electron microscope fitted with a cryo - unit.

For X-Ray spectrometric analysis, the unfixed cultures are also carried over to aluminium slide - cylinders and stuck on them with silver lacquer. The samples are placed in a vacuum evaporator where they are plated with aluminium. For this in. vestigation, we used on the one hand the Jem 100 B Jeol electron microscope equipp. ed with an energy dispersive spectrometer (EDAX system) and on the other hand the Cameca MEB 07 scanning electron

* Laboratoire de Parasitologle et Mycologie, U.E.R. Cordeliers, 15, rue de l'Ecole de Médecine, $75270-$ Paris-CEDEX 06 - France.

* Charge de Recherche au C.N.R.S.

** Chef de Travaux a la Faculté de Médecine de Parls.

Submitted to publication on 12.27.1974. 
microscope equipped with a wavelength ciispersive spectrometer, then the Camebax system, combining in the same assembly an electron microprobe with three wavelenght $\mathrm{X}$-Ray dispersive spectrometers and a scanning electron microscope. With the Camebax system, the analysis is performed with the help of an inclined spectrometer that is capable of using samples up to $1 \mathrm{~mm}$ en diameter.

The general method used in elemental analysis by $\mathrm{X}$-Ray spectroscopy is this: the X-Raỹ spectre emitted under impact of a beam of electrons is composed partly of a continuous spectre and partly of a number of characteristic lines depending on the atoms of the anti-cathode. The small surface of the bombarded sample which plays the part of the anticathode sends out in all directions X-Rays whose spectral analysis is effected by means of the spectrometer. The volume investigated with this technique is $5.000 \mu^{3}$. The crystal detectors used are: acid potassium phthalate (KAP), lithium fluoride (L I F) and penta erythritol (PET).

The cultures of Sporoth:ix schenckii in its mycelial phase are analysed through the combined process of scanning electron microscopy andX-Ray spectroscopy. After obtaining secondary electron images under scanning electron microscopy, some elements belonging to Mendeleef's periodical classification are investigated under X-Ray spectroscopy.

\section{RESULTS}

1) Study under scanning electron microscopy.

The secondary electron images given by scanning electron microscopy show that the hyphae of Sporothrix schenckii are recumbent and make a thick mat (Figs. 1 and 2.). The creeping mycelium branches in all directions and is finely intertangled (Figs. 2, 3 and 4). The plain ovoid conidia are supported directly by undifferentiate hyphae of the vegetative mycelium. They bear no ornaments on their external surfaces (Figs. 5 and 6 ).
2) Study under energy dispersive spectioscopy.

The study of the mycelial phase of Sporothrix schenckii, under Jem $100 \mathrm{~B}$ with Edax system, permits the enumeration of three elemental chemical constituents identified by their $\mathrm{K}^{\propto}$ lines. The PET crystal detector indicates the presence of calcium, sulphur and phosphorus (Figs. 7, 8 and 9).

\section{3) Study under w. velength dispersive} spectroscopy.

a) With the scanning elertron microscope MEB 07 Cumera.

This analysis of the mycelial phase of Sporothrix schenckii confirms the resuits obtained under energy dispersive spectroscopy. The LIF crystal reveals the absence of the following elements: copper, nickel, ccbalt, iron, manganese, chromium, varadium and titanium. The $\mathrm{Zn} \mathrm{K}^{\propto}$ line comes from the slicie cylinder (Fig. 10). With the PET crystal detector appear the $\mathrm{K} \beta$ and $\mathrm{K}^{\propto}$ lines of calcium and the sulphur and phosphorus $\mathrm{K}^{\propto}$ linas. Potassium and chlorine are not identified (Fig. 11). The KAP crystal detector reveals the absence of silicon, magnesium, sodium and fluorine; the aluminium $\mathbf{K}^{\propto}$ line proceeds from the slide and metallization of the cultures (Fig. 12).

\section{b) With the Cumebax system.}

The examination of the mycelial phase permits the detection of eight elementary chemical components. With the LIF crystal detector, the following elements are detected (Fig. 13): calcium ( $\mathrm{K} \beta 2$ line), iodine ( $L^{x}$ line). With the PET crystal detector, the characteristic spectra of the following elements are detected (Fig. 14): iodine ( $L \beta$ and $L^{\alpha}$ lines), calcium $(K \beta$, $K^{\propto} I$ and $K^{\propto}$ II lines), potassium ( $K \beta$ and $\mathbf{K}^{\propto}$ lines), chlorine ( $\mathbf{K}^{\propto}$ line); sulphur ( $\mathbf{K}^{\propto}$ line), phosphorus ( $\mathbf{K} \beta$ and $\mathbf{K}^{\propto}$ lines). With the KAP crystal detector, the following elements are detected (Fig. 15): phosphorus ( $\mathrm{K}^{\propto}$ I and II lines), silicon $\left(\mathrm{K} \beta\right.$ and $\mathrm{K}^{\propto}$ lines), potassium ( $\mathrm{K}^{\propto}$ line $)$, magnesium ( $\mathbf{K}^{\propto}$ line), sulphur $\left(\mathbf{K}^{\propto}\right.$ line).

With these three methods, the natural content to be found in living tissues, 
namely carbon, hydrogen, oxygen and nitrogen, are not investigated. As to the negative results, these techniques may not prove to be useful for infinitesimal quantities. The comparative study of the results shows that microanalysis performed with the Camebax system is much more sensitive than that performed with the Jem 100 B Jeol or with the MEB $07 \mathrm{Ca}$ meca.

\section{DISCUSSION}

A perusal of the literature has enabled us to find that scanning electron microscopy had been used in a number of published works for investigation into pathogenic fungi. Ito, Nozawa, Susuki and Setoguti (9) studied the structures of several strains of Dermatophytes of Microsporun, Epidermophyton and Trichophyton genera. Tosti, Villardita, Fazzini and Scalini (23) analysed the invasion of hair by Dermatophytes under the scanning electron microscope. Thibaut and Ansel $(18,19,20)$ used the same method for studying $R h i$ zopus arrhizus, $R$. equinus and $R$. nigricans and gave a new description of the perithecium of Emericelia niduluns. The surface structure of the spores of Dermatophytes saprophytes and parasites is observed by Smith and Sandler (16). The conidia of the Microsporum gypseum complex were analysed with this technique by Visset (24). And so was the morphology of ascospores of Nannizzia and Arthroderma by Padhye and Carmichaël (15).

investigation of Sporothrix schenckii by means of the scanning electron microscope, shows the surface morphology the recumbent hyphae and the undifferentiatc conidiophores, all of which are used in via. xoncmic studies. They permit to classify this fungus among the Sporotriches

$\mathrm{X}$-Ray microanalysis permits investigation of biological samples which have not been submitted to fixation, dehydration, imbeciding and colouring. This method as perfected by Castaing (5) was first applied to metallurgic and mineralogic samples. It was then applied to biology. In this field microanalysis was used to solve different types of problems such as the analysis of natural mineral content of tissues by Boyde, Switsur and Fernhead (4); the identification of accidentally introduced foreign material by Galle and Berry (7), Berry (1).

In the animal field of biology, Martoja $(13,14)$ resorted to microanalysis to show the distribution of metals in insects, and calcium in the thyroïd gland of some mammals. In plant biology, Thurston and Russ (22) used the same technique to study the structure granules in Fischerella ambigua, a filamentous blue green alga. In Mycology, Gay (8) applied X-Ray spectroscopy to the study of the oospores in Saprolegnia furcata. And we were led, throught this technique, to observe relevant differences in natural chemical content of seven species of Aspergillaceae (21) and unpublished results.

Close investigation was elaborated on the ultrastructural cytolcgy of Sporothrix srhenckii by Thibaut (17), but few authors investigated its biochemistry. Blank (3) determined chitin by applying a method based on X-Ray diffraction. Mariat (11, 12) showed that the cells of the yeast phase of sporcthrix schenckii contain much more deoxyribonucleic acid than those of the mycelial phase. Biêvre (2) identified a number of enzymes: catalase, acid phosphatases, esterases, peroxydases. He alsc measured out the various quantities of lipids, nucleic acids, glycogen, polyDsides and proteins. Lloyd and Bitoon (10) isolated and cleansed a peptidn rhamnomannan purified in the veast whase. But no microanalysis applications had been made on Sporothrix schenckii. In fact, we did not find any difference between the results obtained with the electrcn microscope Jem 100 B equipped with EDAX system and with the scanning electron microscope MEB 07 Cameca. On the other hand, wavelength spectrometry performed with the Camebax system is much more sensitive than the dispersive or non-dispersive spectrometric methods used until now. This technique discloses eight elementary chemical components in the mycelial phase of sporothrix schenckii, wneress the other methods showed three only. 


\section{CONCLUSIONS}

1) Scanning electron microscopy proved to be very efficient for research on the mycelial phase of Sporothrix schenckii. It permitted to discover that the conidiophores are undifferentiated from the vegetative mycelium. So that Sporothrix schenckii is definitely a sporotriche.

2) Analytical electron microscopy allows to provide chemical information without resorting to a variety of stainings or to cifferent instruments. The absence of previous processing allows the preservation of electrolytes. The combination of electron microscopy with $\mathrm{X}$-Ray microana- lysis enables the detection of chemical elements contained in tissues. The advantage is that they permit simultaneous detection on the same sample of the various elements of Mendeleef's periodical classification. This analysis being effected jointly with investigation by scanning microscopy, artefacts are sure to be avoided.

3) Microanalysis enables to detect differences in the elementary chemical constitution of some genera of pathogenic fungi and also of different species of the same genus (21).

4) Wavelength spectrometry with the Camebax system is much more sensitive than the other two methods.

\section{$R E S U M O$}

Sporothrix schenckii foi estudado em microscopia eletrônica. Foram observados caracteres das hífas e dos esporos. Vários elementos da classificação periódica foram postos em evidência graças à micro-análise a raios $X$.

\section{REFERENCES}

1. BERRY J. P., Néphrocalcinose expérimentale par iniection de para. thormone. Etude au microanalyseur à sonảe ślectronique. Néphron. 7: $97-116,1970$.

2. BIEVRE C. de, Etude biochimique et cytologique des formes levures et filamenteuses de Sporothrix schenckii. Thèse Doctorat ès Sciences Naturelles, Paris, 1970.

3. BLANK F., On the cell walls of dimorphic fungi causing systemic infections. Can. J. Microbiol. I: I-5, 1954.

4. BOYDE A., SWITSUR J. R. and FERNHEAD R. W'., Application of the scanning electron probe X-Ray microanalyzer to the dental tissues. J. Ultr. Res. 5: 201-207, 1961.

5. CASTAING R., Application des sondes électroniques à une méthode d'analyse ponctuelle chimique et cristallographique. Thèse Sciences, Paris (O.N.E.R.A.) 92 - Chatillon sous Bagneux, 1952.

6. GALLE P.. Analyse chimique ponetuelle des inclusions intra-cellulaires par spectrographie des rayons $\mathrm{X}$. Application à l'étude des cellules rénales. Thèse Sciences Paris (L'Expansion, Paris), 1965.
7. GALLE P. et BERRY J. P., Cytochimie élémentaire ultrastructurale sur coupes ultrafines de poumon. Le poumon et le coeur, 25: 307-317, 1969.

8. GAY J. L., X-Ray microanalysis in the development of oospores of the fungs Saprolegnia. Micron. 3: 139-143, 1972.

9. ITO Y., NOZAWA Y., SUSUKI $H$. and SETOGUTI $T$., Surfaces structures of Dermatophytes as seen by the scanning electron microscope. Sabouraudia, 7: 270-272, 1970.

10. LLOYD $\mathbf{K}$. O. and BITOON $\mathbf{M}$. $\mathbf{A}$. Isolation and purification of a peptidorhamnomannan from the yeast form of Sporothrix schenckii. structural and immunological studies. $J$ Immunol. 107: 663-671, 1971.

11. MARIAT F., Sur la teneur en acides $_{S}$ nucléiques des formes levures et mycéliennes de Sporothrix schenkii. C. R. Acad. Sc. 248: 3468-3469, 1959.

12. MARIAT F., Sur la composition en acides nucléiques de la phase mycélienne de S. schenckii. C. R. Acad. Sc. 250: 3368, 1960. 
13. MARTOJA M., Répartition du calcium cians la glande thyroïde de quelques Mammifères. C. R. Acad. SC. 272: 3173-3175, 1971.

14. MARTOJA R., Des insects et des métaux. La Recherche, 18: 1074$1075,1971$.

15. PADHYE A. M., and CARMICHAEL J. W., Ascospore morphology of Nannizzia and Arthroderma species by scanning electron microscopy. $S a-$ bouraudia, 10: 313-314, 1972.

16. SMITH J. M. B., and SANDLER W. J. U., The surface structure of saprophytic and parasitic dermatophytes spores. Mycopathologia et Mycologia applicata, 43: 153-159, 1971.

17. THIBAUT M., Etude biologique, morphologique, cytologique et taxinomique du Sporothichum schenckii (Hetkoen et Perkins) de Beurmann et Gougerot: Dolichoascus schenckii ( $\mathrm{H}$ et $P$ ) Thibaut et Ansel 1970. Thèse Doctorat d'Etat ès Sciences, Paris (Dactylo Sorbonne, Paris), 1970.

18. THIBAUT $\mathbf{M}$. et ANSEL $\mathbf{M}$., Essai d'utilisation du microscope électronique à balayage, pour l'étude morphologique des champignons. Annales de Parasitologie humaine et comparée, 46: 103-107, 1971.

19. THIBAUT $\mathbf{M}$. et ANSEL M., Nouvelle description d'un périthèce d'As- comycète. Annales de Parasitologie humaine et comparée, 47: 159-167, 1972.

20. THIBAUT $M$. et ANSEL M., Examination of mycological samples by means of the scanning electron microscope. Rev. Soc. Bras. Med. Trop. 7: 79-85, 1973.

21. THIBAUT $M$. et ANSEL M., Recherches en spectrométrie à Rayons $\mathrm{X}$ sur la constitution chimique élémentaire de l'Aspergillus fumigatus Frésénius et de l'Aspergilius niger van Tieghem. J. Microscopie, 17: 100, 1973.

22. THURSTON E. L. and RUSS J. C., Scanning and transmission electron microscopy and microanalysis of structured granules in Fischerella ambigua. Scanning electron microscopy. Proceedings of the fourth annual scanning electron microscope symposium (Chicago, ed. I.I.T. Research Institute), 1971.

23. TOSTI A., VILLARDITA S., FAZZINI M. L. and SCALICI R., Contribution to the knowledge of dermatophytic invasion of hair. Journal of Investigative Dermatology, 55: 123134, 1970.

24. VISSET $M$. F., Les formes conidiennes du complexe Microsporum gypseum observées en microscopie électronique à balayage. Sabouraudia, 10: 191-192, 1972. 


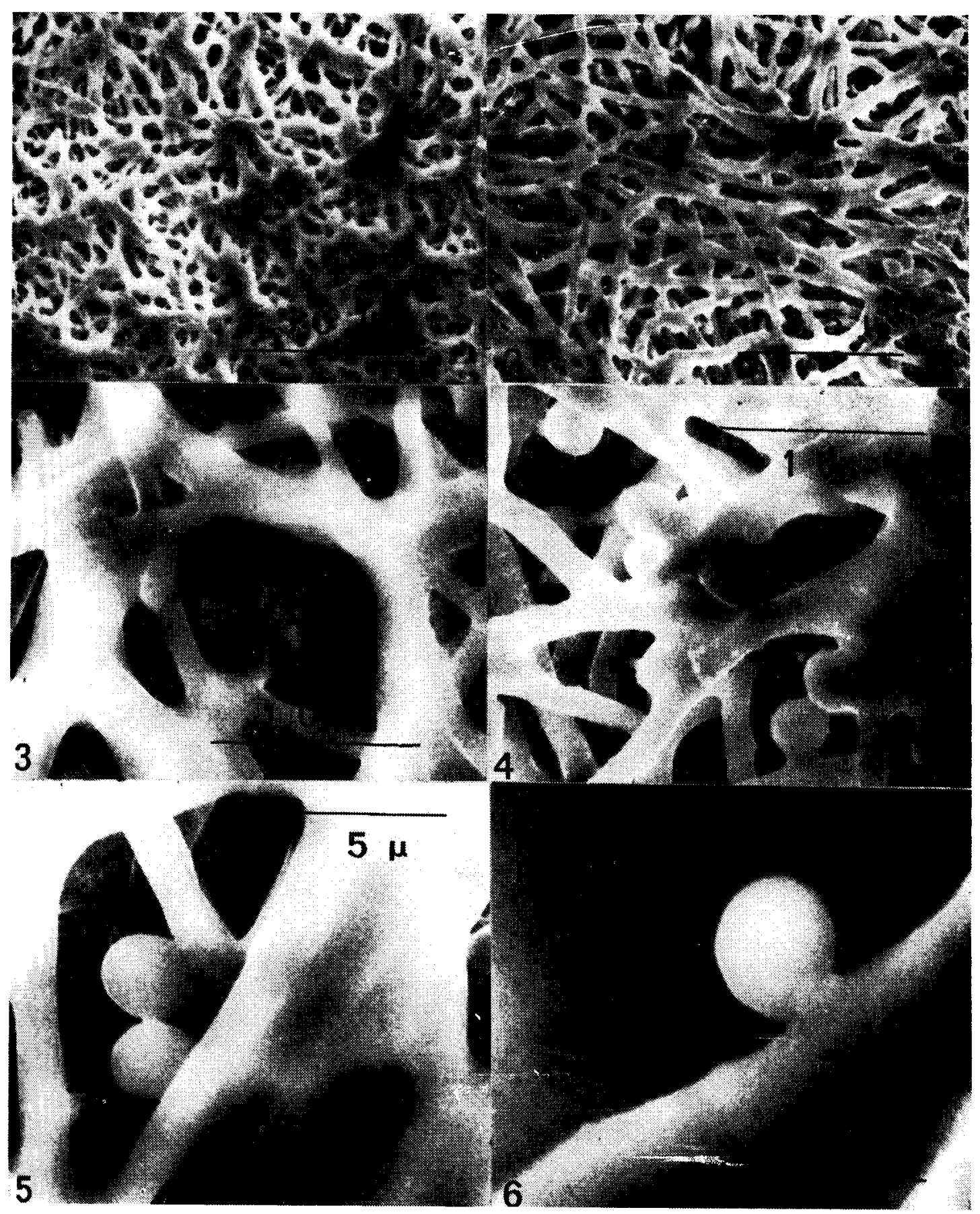


Fig. 1 - Culture of Sporothrix schenckii in its mycelial phase. Secondary electron image obtained by scanning electron microscopy. Mycelium padded.

Fig. 2 - Culture of sporothrix schenckii in its mycelial phase. Scanning electron microscopy. Mycelium padded and plain ovold conidia.

Fig. 3-Conidia and creeping mycelium of sporothrix schenckii as shown by the scanning electron microscope.

Fig. 4 - The myceltal phase of Sporothrix schenckii (scanning electron microscopy). Creeping mycelium branching out in all directions and finely intertangled. The plain ovoid conidia are supported directly by undifferentiate hyphae.

Fig. 5 - Two ovoid conidia. They bear no ornaments on their external surfaces.

Fig. 6 - Hight magnification of a conidia. 

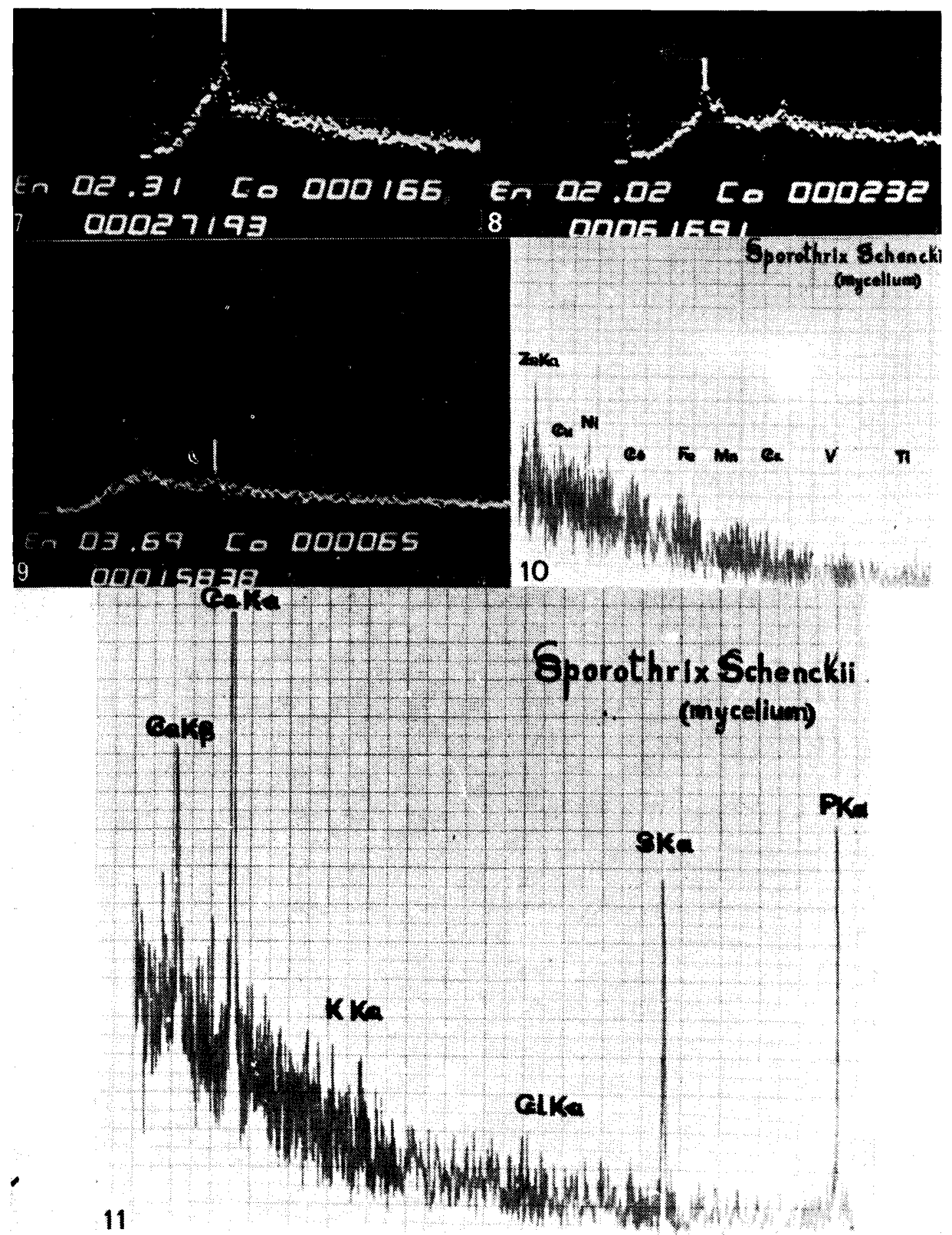
F1g. 7 - Ca Ka X-Ray image obtained by energy dispersive spectroscopy (Jem $100 \mathrm{~B}$ with Edax system). PET crystal detector; accelerating voltage $40 \mathrm{Kv}$.

Fig. 8 - S $\mathbf{K} \propto$ X-Ray image obtained by energy dispersive spectroscopy (Jem 100 B with Edax system). PET crystal detector: accelerating voltage $40 \mathrm{Kv}$.

Fig, $9-\mathbf{P} \mathbf{K} \propto$ X-Ray image obtained by energy dispersive spectroscopy (Jem $100 \mathrm{~B}$ with Edax system). PET crystal detector: accelerating voltage $40 \mathrm{Kv}$.

Fis. 10 - Study of the mycelial phase of Sporothrix schenckii under wavelength dispersive spectroscopy (MEB 07). The LIF crystal detector reveals the absence of copper, nickel, cobalt, iron manganese, chromium, vanadium, and titanium. The $\mathrm{Zn} \mathrm{K}$ line comes from the slide cylinder. Conditions required for detection: accelerating voltage $20 \mathrm{Kv}$, current delivered 400 $\mathrm{nA}, 100$ pulses/second.

Fis. 11 - Study of the mycelial phase of Sporothrix schenckii under wavelength dispersive spectroscopy with PET crystal detector (MEB 07). The $\mathrm{Ca} K \beta$ and $K \propto \mathbf{X}$-Ray images are identified as well as the $S$ and $P, K \infty$-Ray images. The following conditions are required for detection: accelerating voltage $20 \mathrm{Kv}$, current delivered $200 \mathrm{nA}, 100$ pulses/second. 

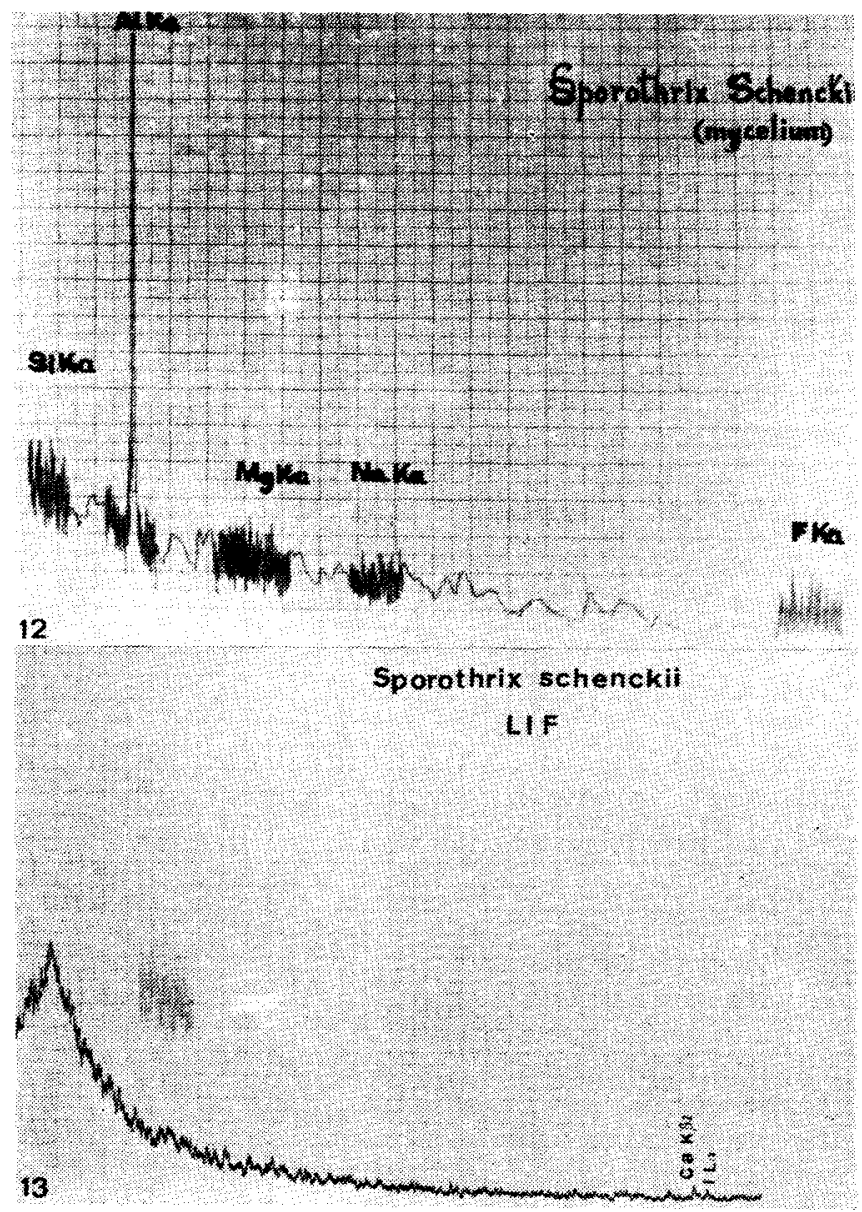

Fig. 12 - Study of the mycelial phase of Sporothrix schenckii under wavelength dispersive spectroscopy with KAP crystal detector (MEB 07). No elements are detected except the Al $\mathbf{K} \propto \mathbf{X}$-Ray image due to the slide cylinder and metallization of culture. Conditions required for detection: accelerating voltage $20 \mathrm{Kv}$, current delivered $100 \mathrm{nA}, 100$ pulses/second.

Fig. 13 - Study of the mycelial phase of Sporothrix schenckii under wavelength dispersive spectroscopy (Camebax system). With LIF crystal detector are identified: calcium ( $K \propto$ II line) and Iodine ( $L \propto$ line). Conditions required for detection: $20 \mathrm{Kv}$, $50 \mathrm{nA}$. 


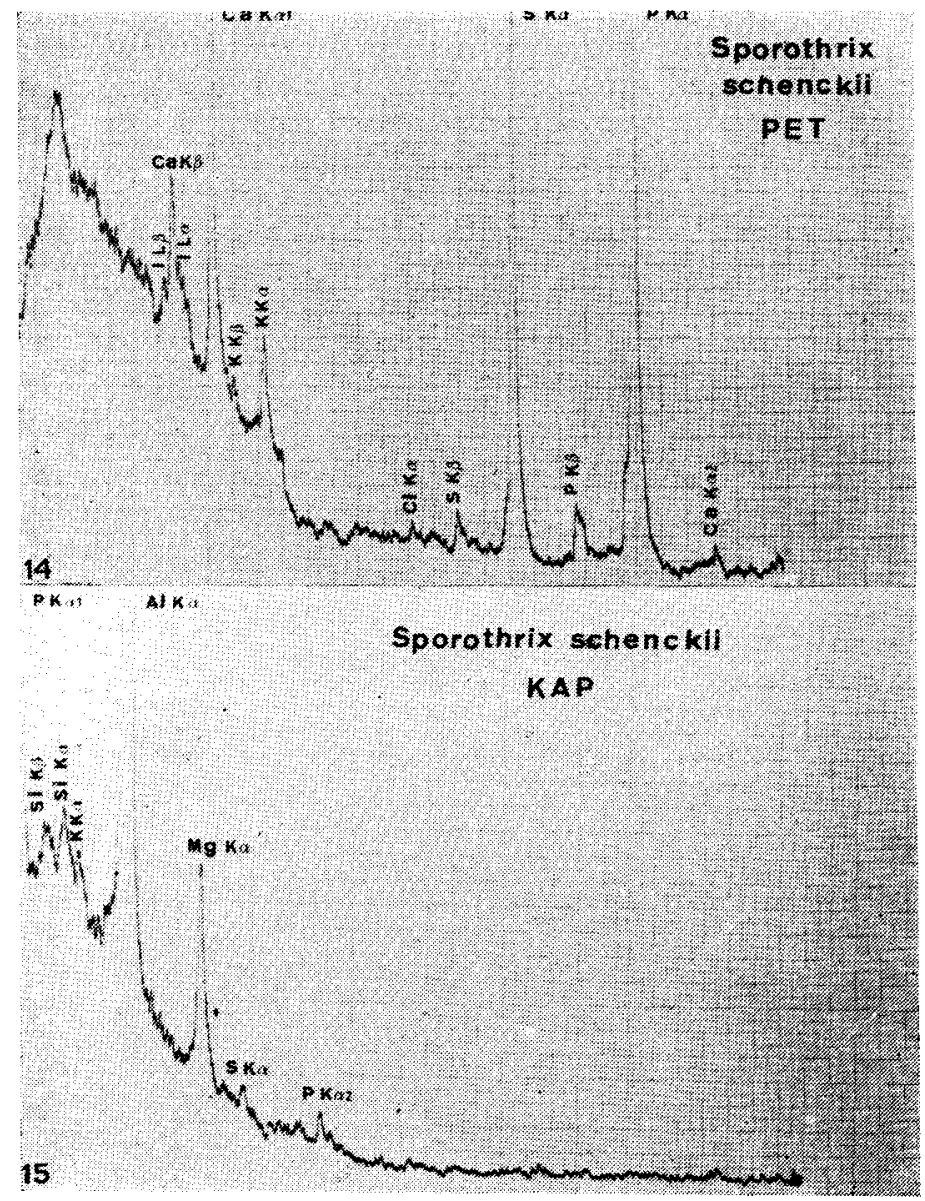

Fig. 14 - Study of the mycelial phase of Sporothrix schenckii under wavelength dispersive spectroscopy (Camebax system). With PET crystal detector are identified: Iodine ( $\mathrm{H} \beta$ and $L$ ro lines), calcium ( $K \beta, \mathbf{K} \propto I$ and II lines), potassium ( $K \beta$ and $\mathbf{K} \propto$ li-

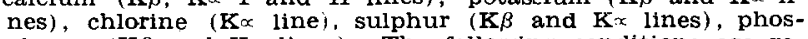
phorus ( $K \beta$ and $K \propto$ lines). The following conditions are required for detection: $20 \mathrm{Kv}, 50 \mathrm{nA}$.

Fig. 15 - Study of the mycelial phase of Sporothrix schenckii under wavelength dispersive spectroscopy (Camebax system). With KAP crystal detector are identified: phosphorus ( $K \propto \mathrm{I}$ and II lines), silicon ( $\mathrm{K} \beta$ and $\mathrm{K} \times$ lines), potassium ( $\mathrm{K} \times$ line), magnesium $(K \propto$ line $)$, sulphur $(\mathrm{K} \propto$ line $)$. Conditions required for detection: $20 \mathrm{Kv}, 50 \mathrm{nA}$. 